\title{
Kamień podkrakowskich budowli romańskich
}

\author{
Jan Bromowicz ${ }^{1}$, Janusz Magiera ${ }^{1}$
}

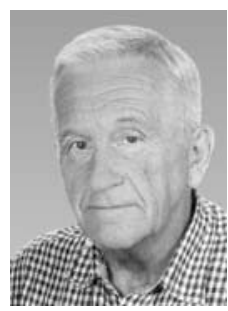

J. Bromowicz

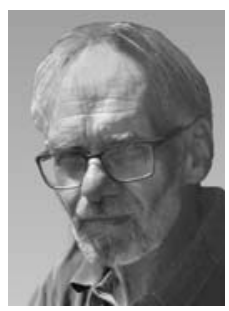

J. Magiera

Building stones used in Romansque edifices in the vicinity of Kraków. Prz. Geol., 69: 103-108; doi: $10.7306 / 2021.5$

A b s tra ct. Three objects were studied within a project aimed at investigation of stones used in the Romanesque edifices in the vicinity of Kraków, and continued since 2019. These are the churches in Dziekanowice (21 km SE of Kraków) and in Czchów (58 km SE of Kraków), and a clergy house in Morawica (13 W of the Krakwó city centre). The church in Dziekanowice is relatively completely and well preserved, while the only Romanesque remnants of the church in Czchów are those reused in the Gothic church. It is a clergy house in Morawica (a former castle), whose walls contain Romanesque fragments. Two former edifices are built of the Istebna sandstone (Upper Cretaceous-Paleogene), quarried from the local flysch bedrock. Fine-grained, grey-yellowish stone dominates. It is soft and easily workable due to argillaceous binder (matrix). The stone blocks are precisely shaped and well fitted. Romanesque remnants of the clergy house in Morawica are constructed predominantly of limestone, also of local origin. Only a fragment of the $N W$ wall is built of the Istebna sandstone. This fragment is probably a part of the butress supporting the NW wall. The study shows that stonemasons and builders of that time had good skills of selecting and applying proper stone blocks for particular purposes. Blocks used in load-bearing structures were exceptionally well shaped and fitted. On the other hand, those skills varied. The frieze from the Romanesque church in Czchów is rather primitive. The size of limestone blocks used in the clergy house in Morawica is strikingly similar to those of various Romanesque edifices in Kraków. It seems, therefore, that those blocks could have been quarried and shaped in quarries located in the city, where the masonry "industry" was well developed. Larger, irregular blocks, used as foundations and filler in the "opus emplectum" type walls were probably quarried on site. Moreover, stones used in more eminent edifices (churches, castles) were probably more carefully selected. The Morawica castle (clergy house) and many churches in Krakwó were built of limestone blocks without cherts.

Keywords: Romanesque period, masonry, Istebna sandstone, Upper Jurassic limestone

W artykule przedstawiamy wyniki badań kościołów usytuowanych na południe od Krakowa - w Dziekanowicach i Czchowie, oraz budowli w Morawicy, położonej tuż przy zachodniej granicy Krakowa. Działalność ta jest kontynuacją obserwacji z ubiegłego roku, wykonanych w znajdujących się na północ od miasta kościołach w Wysocicach, Prandocinie i Kościelcu Proszowickim (Bromowicz, Magiera, 2019). Podobnie jak wtedy, opisane świątynie są zapewne pierwszymi kamiennymi budowlami wzniesionymi w wymienionych miejscowościach. Stąd też interesujący jest wybór zastosowanego materiału kamiennego, jego pochodzenie i sposób obróbki na tle budowy geologicznej otoczenia, pozwalający na ocenę umiejętności wykonawców opisywanych obiektów.

\section{KOŚCIÓŁ W DZIEKANOWICACH}

Kościół pod wezwaniem św. Marii Magdaleny i św. Mikołaja (ryc. 1) jest oddalony o $21 \mathrm{~km}$ w linii prostej od Wawelu. Położony jest na Pogórzu Wielickim w pobliżu krawędzi lewej terasy rędzinnej Raby, przy szlaku handlowym łączącym Kraków z Nowym Targiem przez Wieliczkę i Dobczyce. Jest to obszar zamieszkany już od pierwszej fazy wczesnego średniowiecza, o czym świadczą opisywane przez Zoll-Adamikową (1959) kurhany w pobliskim Zakliczynie i Koźmicach Wielkich. Centrum tego obszaru stanowił zamek Kazimierza Wielkiego w pobliskich Dobczycach.

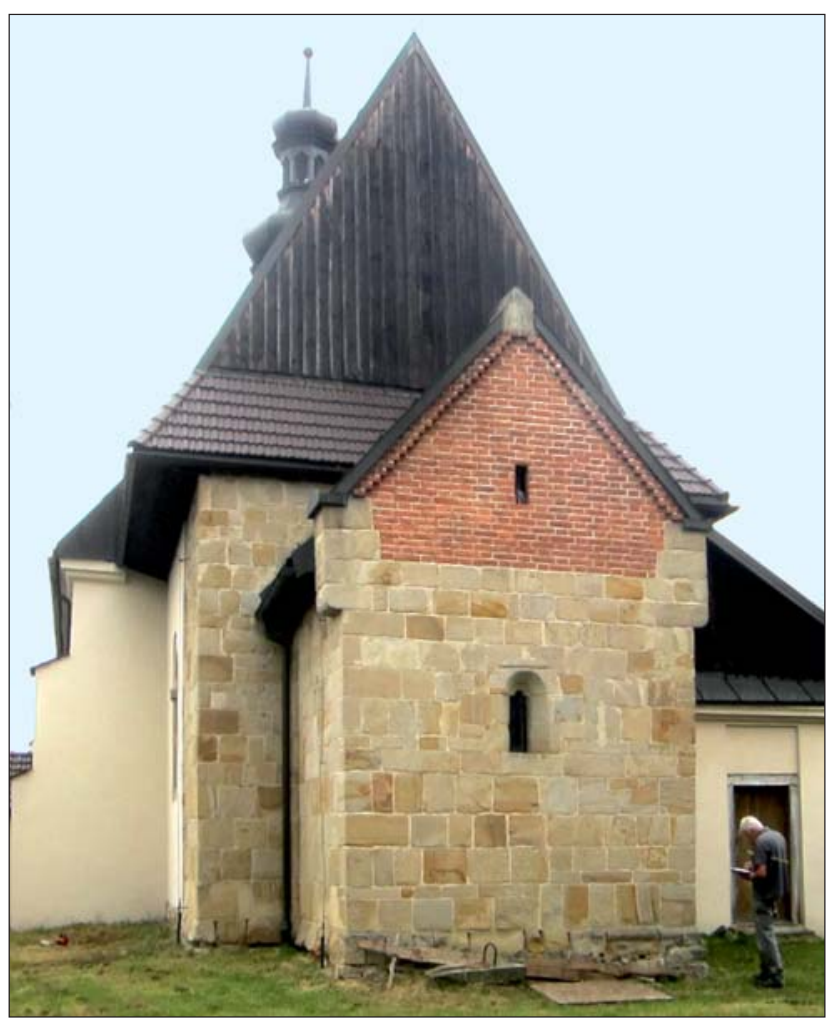

Ryc. 1. Kościół w Dziekanowicach. Widok od strony prezbiterium Fig. 1. Church in Dziekanowice. View from the presbytery

\footnotetext{
${ }^{1}$ Akademia Górniczo-Hutnicza, al. Adama Mickiewicza 30,30-059 Kraków; bromow@geol.agh.edu.pl; magiera@geol.agh.edu.pl
} 


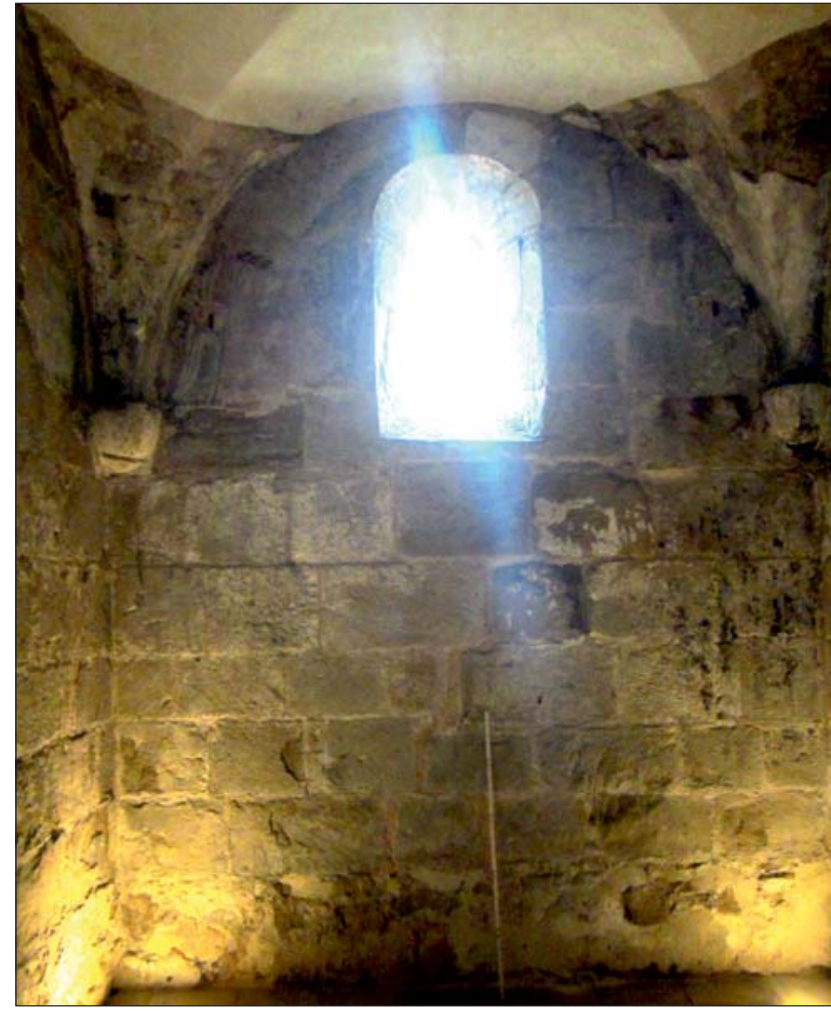

Ryc. 2. Kościół w Dziekanowicach. Wnętrze prezbiterium Fig. 2. Church in Dziekanowice. Presbytery inside

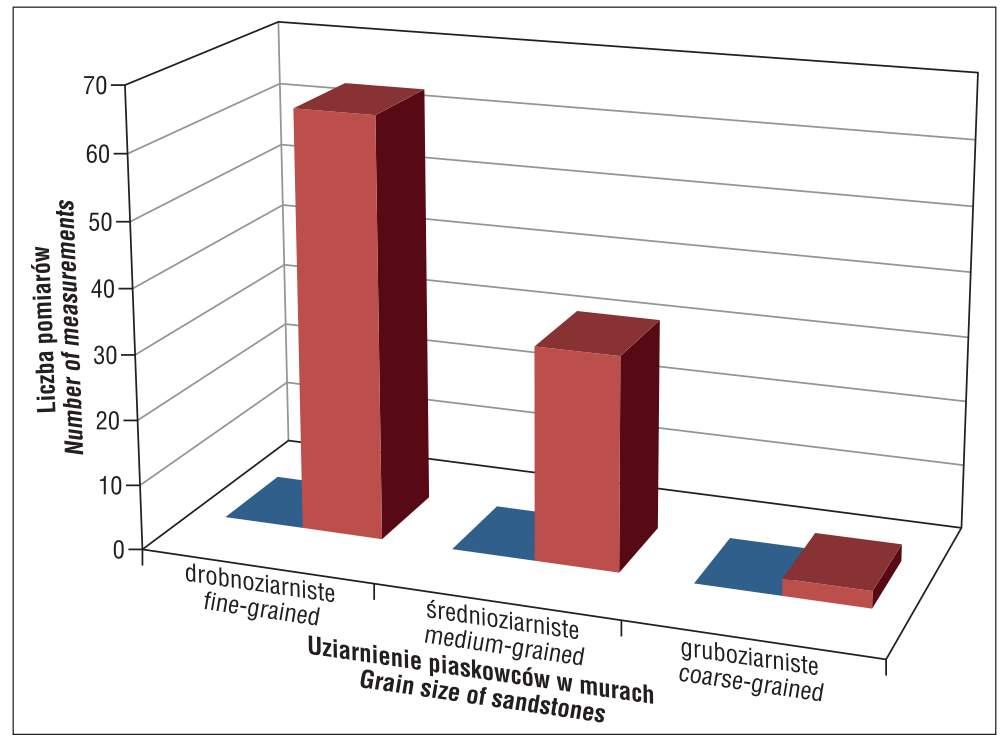

Ryc. 3. Kościół w Dziekanowicach. Rozkład uziarnienia piaskowców w murach Fig. 3. Church in Dziekanowice. Distribution of the grain size of sandstone in the walls

Romański kościół jest złożony z niewielkiego prostokątnego prezbiterium o wymiarach wewnętrznych, wg pomiarów Jodłowskiego $(1977)-2,48 \times 2,90 \mathrm{~m}$ i nieco większej nawy $(6,40 \times 5,15 \mathrm{~m})$, które mimo dwukrotnej rozbudowy świątyni zachowały się w dużej części. Grubość murów wynosi od 0,7 do $0,9 \mathrm{~m}$. W prezbiterium pozostały narożne stopy sklepienia, wsparte na kamiennych, ćwierćkulistych, zaostrzonych dołem wspornikach, oraz głęboko rozglifione, zasklepione okrągłym łukiem okno w ścianie wschodniej (ryc. 2). W ścianie południowej znajduje się prostokątna wnęka, wg Dutkiewicza (1964) prze- znaczona zapewne na oleje święte, zaś w północnej - wnęka sklepiona trójkątnie, zaplanowana na cyborium. Ściany prezbiterium pokrywały romańskie polichromie opisane przez Dutkiewicza (1964).

Kościół jest zbudowany z dużych, starannie obrobionych ciosów piaskowcowych z licznymi znakami kamieniarskimi (gmerkami). Zarówno rozwiązania architektoniczne, jak i wspomniane polichromie datuja powstanie kościoła na wiek XIII. Istnienie parafii w roku 1270 jest wg Świechowskiego (2000) potwierdzona w opisach cudów św. Jacka.

Kamienie w murach są piaskowcami o różnym uziarnieniu i zabarwieniu. Najczęściej są szare i żółtordzawe, drobnoziarniste, rzadziej średnio- i sporadycznie gruboziarniste. We wschodniej ścianie prezbiterium ich udział wynosi odpowiednio 65,32 i $2 \%$ (ryc. 3). Są to niezbyt zwięzłe, bezwapniste piaskowce $\mathrm{z}$ widocznymi wśród grubego ziarna szarymi kwarcami i białymi skaleniami. Wymiary zastosowanych ciosów wewnątrz prezbiterium, $\mathrm{w}$ jego murach zewnętrznych oraz $\mathrm{w}$ nawie są podobne i wynoszą średnio od 24,8 do 27,2 cm (wysokość) i od 33,9 do 39,7 cm (długość) (ryc. 4). Zmienność tych wymiarów jest większa w murach zewnętrznych (gdzie współczynnik zmienności wynosi od 27 do $39 \%$ ) niż we wnętrzu prezbiterium (17\%), co może wskazywać na specjalnie dobieraną wielkość kamienia do murów wewnętrznych.

\section{KOŚCIÓŁ W CZCHOWIE}

Czchów jest oddalony od Wawelu o $58 \mathrm{~km}$ w kierunku południowo-wschodnim i położony na Pogórzu Wiśnickim, w obrębie płaszczowiny śląskiej. Nieznane jest usytuowanie romańskiego kościoła, z którego pozostały jedynie kamienne ciosy wykorzystane $\mathrm{w}$ przyporach kościoła gotyckiego (ryc. 5A) i fragmenty fryzu wmurowanego we wschodnią ścianę jego prezbiterium (ryc. 5B). Z pierwotnym, romańskim kościołem są też wiązane piaskowcowe rzeźby gryfa i lwa. Pierwsza, stanowiąca zapewne fragment archiwolty portalowej wspomnianego kościoła, jest eksponowana w Muzeum Narodowym w Krakowie, lew zaś na czchowskim rynku.

Romański kościół istniał zapewne już w wieku XII, gdyż jest rejestrowany w latach 1325 1327 jako kościół parafialny i określony białym kościołem w dokumencie lokacyjnym z roku 1357, a Jan Długosz opisuje go jako murowany, wzniesiony przez niemieckich kolonistów (Chrzanowski, Kornecki, 1982; Świechowski, 2000).

Wysokość pomierzonych 230 ciosów z przypór wschodniej ściany prezbiterium kościoła $\mathrm{w}$ Czchowie ma średnio $33,4 \mathrm{~cm}$, zaś długość - 38,7 cm, przy współczynnikach zmienności odpowiednio 23,4 i 32,8\%. Wysokości i długości większości kształtek mieszczą się w przedziale $24-40 \mathrm{~cm}$. Piaskowce zarówno przypór, jak i wyżej wymienionych rzeźb są podobne do zastosowanych w murach kościoła w Dziekanowicach - dosyć miękkie, nierównoziarniste, w przewadze drobnoziarniste, rzadziej średnioziarniste, o barwach szarych i żółtordzawych, sporadyczne czerwonych, co zapewne jest spowodowane wysoką temperaturą 


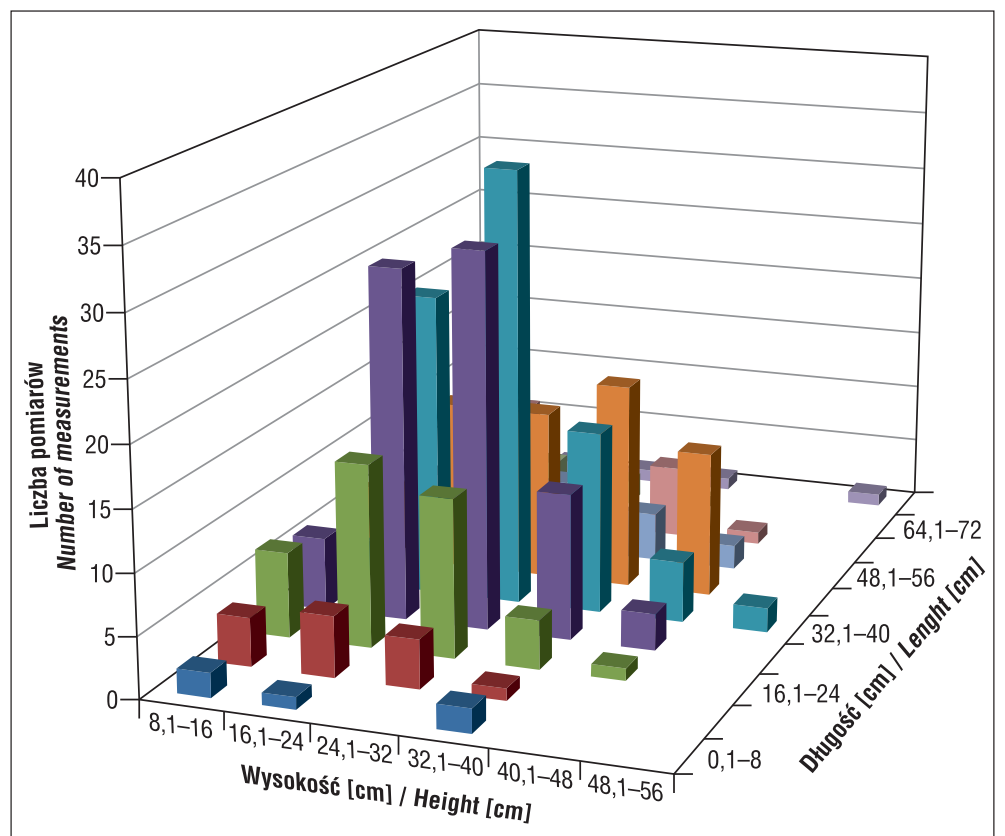

$\leftarrow$

Ryc. 4. Kościół w Dziekanowicach. Rozkład wymiarów ( $\mathrm{w} \mathrm{cm}$ ) ciosów piaskowcowych w murach Fig. 4. Church in Dziekanowice. Distribution of size (in $\mathrm{cm}$ ) of the sandstone blocks in the walls

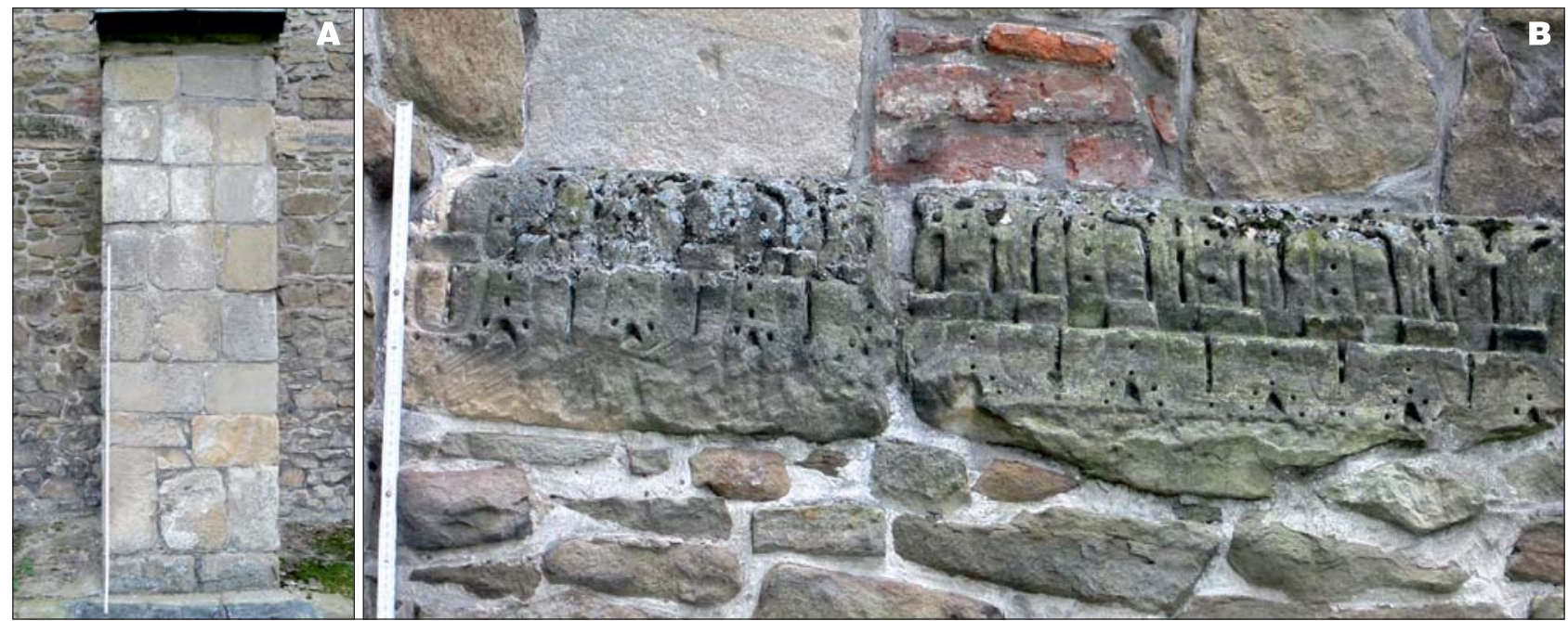

Ryc. 5. Gotycki kościół w Czchowie. A - przypora zbudowana z piaskowcowych ciosów kościoła romańskiego, B - romański fryz Fig. 5. Gothic church in Czchów. A- butress constructed of blocks of the Romanesque church, B - Romanesque frieze

towarzyszącą pożarom. Ich charakterystycznym, widocznym makroskopowo składnikiem, są białe skalenie w kilkuprocentowym udziale. Znamienna jest też niewielka zwięzłość, wskazująca na słabe i skąpe spoiwo, oraz wielkość ciosów, sięgająca $100 \mathrm{~cm}$, co świadczy o znacznej miąższości ławic, z których zostały odspojone. Wszystkie te cechy posiadają piaskowce istebniańskie występujące w podłożu kościoła w Dziekanowicach i w nieco większej odległości, rzędu $1 \mathrm{~km}$, od kościoła w Czchowie.

Wielkości stosowanych ciosów piaskowcowych i ich zróżnicowanie są podobne do gabarytów ciosów zastosowanych w murach romańskich kościołów Krakowa (Bromowicz, Magiera, 2015). Ich średnia wysokość zwykle nie przekracza $30 \mathrm{~cm}$, długość - $40 \mathrm{~cm}$, zaś trzeci wymiar, znany z naroży budowli, ok. $20 \mathrm{~cm}$. Dają one bryłę o objętości $0,024 \mathrm{~m}^{3}$ i ciężarze ok. $60 \mathrm{~kg}$, która wydaje się optymalna do transportu i wznoszenia murów i daje się pozyskać z różnych wychodni warstw istebniańskich, niekoniecznie tych najgrubiej uławiconych.

\section{BUDOWLA W MORAWICY}

Morawicę od Wawelu dzieli w linii prostej $13 \mathrm{~km}$. Prezentowana budowla jest położona na wzniesieniu ograniczającym od zachodu lotnisko w Balicach. Jest to plebania wznosząca się obok górującego nad okolicą kościoła pw. św. Bartłomieja (ryc. 6). Wzniesienie stanowi jurajski ostaniec denudacyjno-erozyjny, przykryty pokrywą lessową, usytuowany na południowo-wschodnim skraju, przynależnego do Jury Krakowsko-Częstochowskiej, zrębu Pasma Tęczyńskiego. Miejsce to od lat było wiązane przez archeologów i historyków z najstarszym polskim rodem rycerskim Toporczyków (Kurtyka, 1995-1996), którego pierwszym historycznym przedstawicielem był Sieciech, palatyn Władysława Hermana i fundator kościoła św. Andrzeja w krakowskim Okole. Wzmianki historyczne dotyczące najpierw parafii, a potem palatium możnowładczego zwanego zamkiem w Morawicy, pojawiają się w połowie XIII w. (Kwaśnik, 2010). W roku 1666 Izabela Opalińska, córka ostatniego z morawickich Toporczyków - Jana Magnusa 


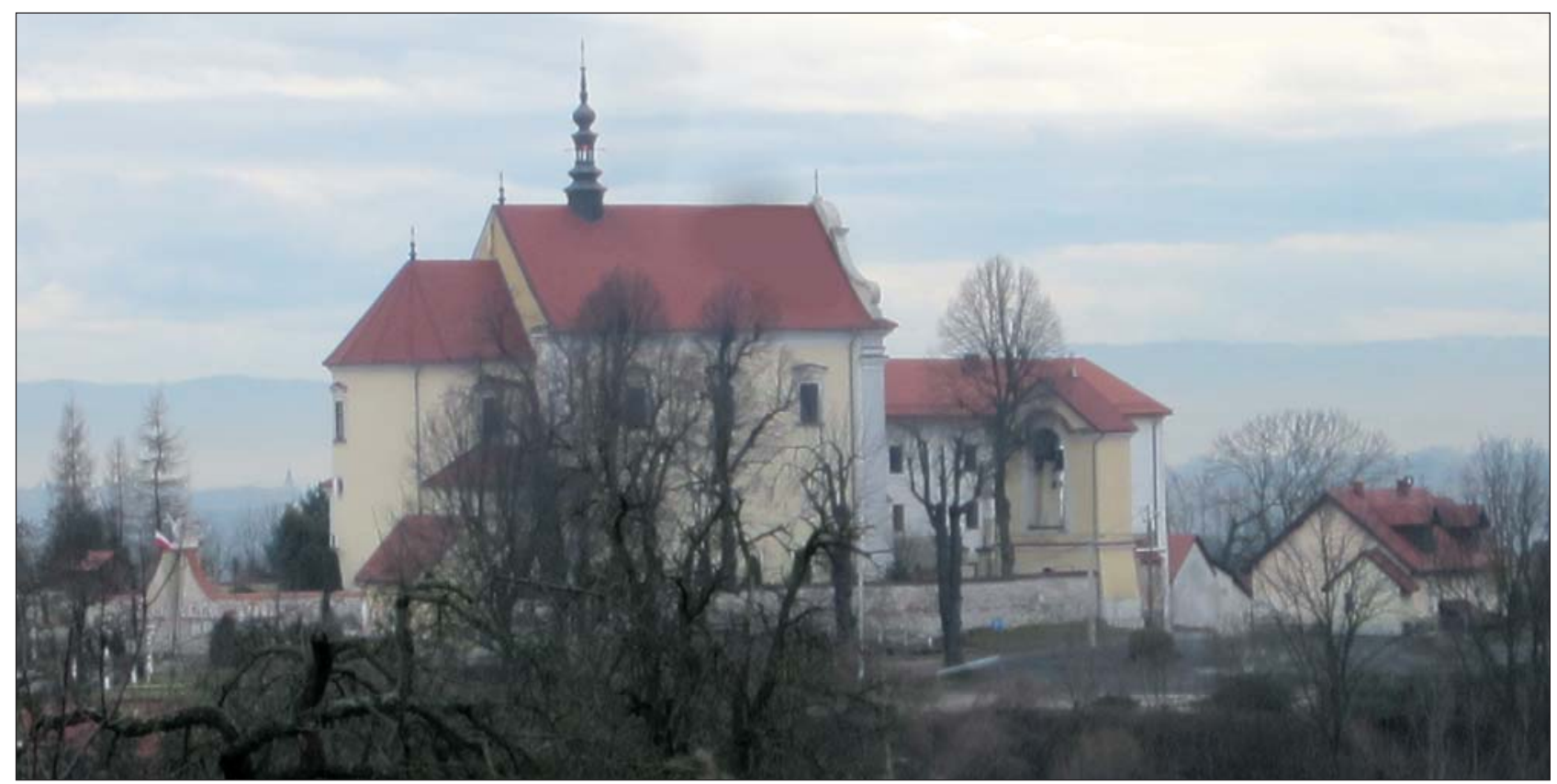

Ryc. 6. Morawica. Kościół pw. św. Bartłomieja i plebania (po prawej)

Fig. 6. Morawica. Church of St. Bartholomew and clergy house (on the right)

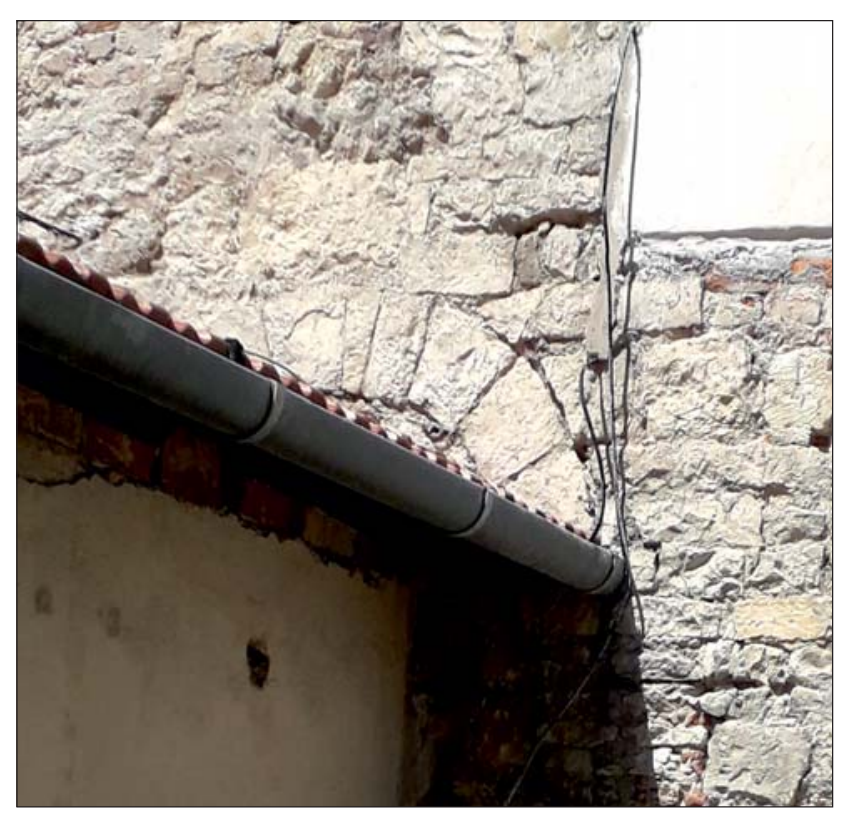

\section{$\leftarrow$}

Ryc. 7. Morawica. Łuk portalu romańskiego w ścianie plebanii Fig. 7. Morawica. Arch of the Romanesque portal in the wall of the clergy house

Tęczyńskiego, podarowała zamek parafii. Jego część została adaptowana na plebanię, w części zaś wzniesiono kościół i dzwonnicę. 350 lat później odpadający tynk ukazał w południowej ścianie plebanii wapienny łuk portalu rozpoznany jako romański (Bicz-Suknarowska, 2019) (ryc. 7).

Dalsze odkrywki pokazały mury o grubości ok. $1 \mathrm{~m}$ wykonane w technice opus emplectum, których lica są zbudowane z wapiennych kształtek, zaś wnętrze wypełnione nieregularnymi bryłami wapiennymi, zalanymi wapienna zaprawą. Budowla ma kształt prostokąta o wym. $17 \times 7 \mathrm{~m}$. Mury zostały zachowane aż do wysokości pierwszego piętra, co jest rzadkim przypadkiem wśród zachowanych budowli romańskich.

Mury romańskie odsłaniają się we fragmentach ściany

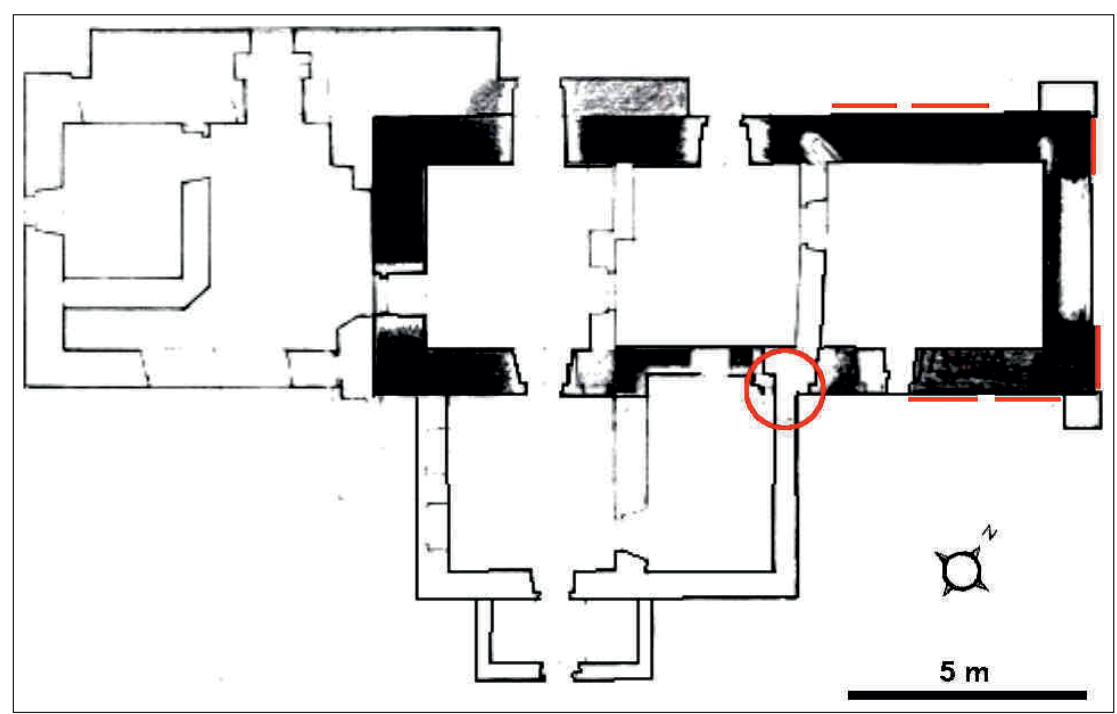
północno-wschodniej, północno-zachodniej i południowo-zachodniej (ryc. 8). Widoczne tam wapienie pelityczne są zwięzłe, mają barwę szarą i szarobrązową, po zwietrzeniu białą. Buduje je jednolita masa wapienna bez udziału

\section{$\leftarrow$}

Ryc. 8. Morawica. Rzut murów plebanii, czarne - mury romańskie (wg Bicz-Suknarowskiej, 2019), czerwony okrag - łuk romańskiego portalu, czerwone linie miejsca obserwacji i pomiarów

Fig. 8. Morawica. Map of the walls - Romanesque walls marked in black (after Bicz-Suknarowska, 2019), red circle Romanesque arch, red lines - observed and measured fragments of the walls 


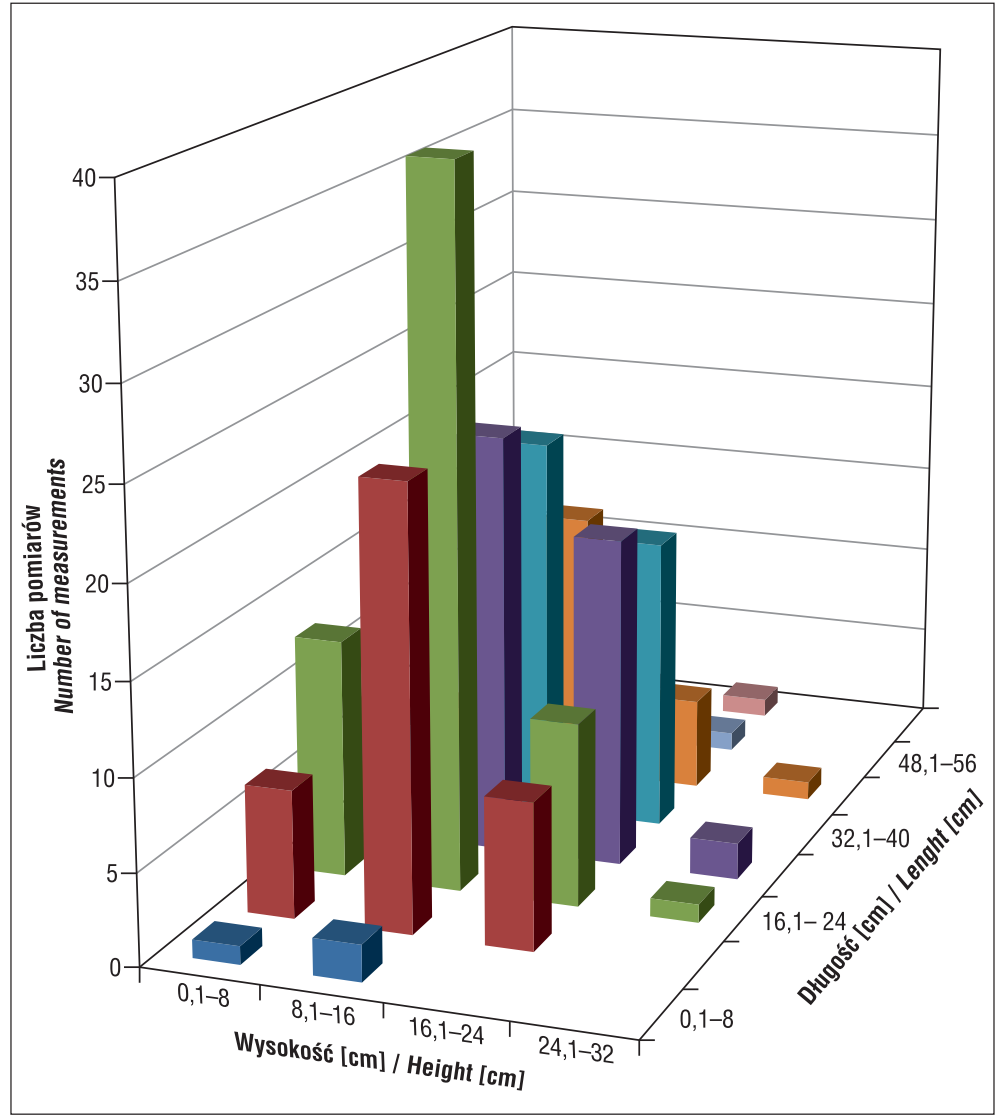

Ryc. 9. Morawica. Rozkład wymiarów (w cm) kształtek kamiennych (bez części środkowej ściany NW)

Fig. 9. Morawica. Distribution of size (in $\mathrm{cm}$ ) of the stone blocks in the Romanesque walls (except for the middle part of the NW wall)

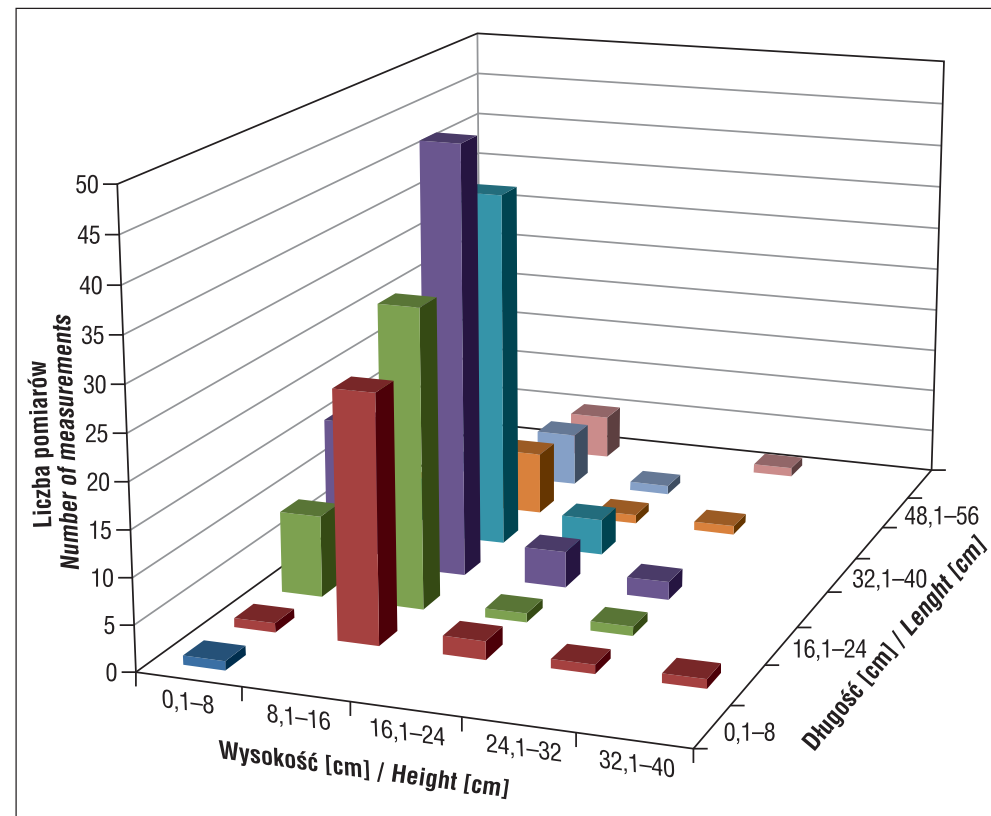

Ryc. 10. Morawica. Rozkład wymiarów (w cm) kształtek kamiennych w części środkowej ściany NW

Fig. 10. Morawica. Distribution of size (in $\mathrm{cm}$ ) of the stone blocks in the middle part of the NW Romanesque wall

dostrzegalnych makroskopowo składników. Wapienie drobnodetrytyczne, o składnikach sięgających $2 \mathrm{~mm}$, są również zwięzłe i o podobnych barwach jak poprzednie. Zawierają zwykle drobne kawerny o wielkości od 0,5 do
1,0 mm, czasem wypełnione kryształami kalcytowymi. Wapienie odmiany grubodetrytycznej zawierają bio- i intraklasty o wielkości sięgającej $10 \mathrm{~mm}$, którym towarzyszą kawerny o podobnych średnicach. Wśród nich występują też wapienie zlepieńcowate, złożone z ostrokrawędzistych, kilkucentymetrowych okruchów wapiennych, silnie ze sobą połączonych, widocznych na powierzchniach nadwietrzałych. Znamienny jest brak krzemieni, dosyć często pojawiających się w jurajskich wapieniach.

Piaskowce występują tylko w środkowej części ściany północno-zachodniej. Są one bezwapniste, średnio- i drobnoziarniste, o barwie szarej i żółtordzawej. Wśród materiału okruchowego przeważa frakcja $0,2-0,5 \mathrm{~mm}$, z pojedynczymi ziarnami do $3 \mathrm{~mm}$. W składzie mineralnym dominuje kwarc, dosyć częste są skalenie o silnie zaznaczonych procesach wietrzenia i okruchy skalne reprezentowane przez granitoidy, łupki łyszczykowe i skały krzemionkowe. Mik prawie zupełnie brak. Spoiwa jest niewiele, są liczne puste pory. Ziarna się stykają, tworząc różne rodzaje kontaktów. Interstycja są puste.

Wielkości kształtek użytych w różnych częściach badanych murów są podobne. Ich wysokość wynosi 12-14 cm, przy współczynniku zmienności rzędu 30-40\%, a długość $27-28 \mathrm{~cm}$ (przy zmienności 40-45\%). Pomimo podobieństwa średnich wymiarów kształtek w badanych fragmentach omawianej budowli, nieco odmienny jest rozkład ich wielkości ze środkowej części ściany północno-zachodniej w porównaniu do pozostałych. Widać to w podobnym rozkładzie z połączonych części (NE i SE) ściany północno-wschodniej budowli. W części środkowej ściany północno-zachodniej zróżnicowanie wysokości kształtek jest znacznie mniejsze i zawiera się głównie w przedziale 8,1-16,0 cm, podczas gdy w ścianie północno-wschodniej są to głównie przedziały $0,1-8,0$ i 16,1-24,0 cm (ryc. 9, 10).

Są też różnice w inwentarzu skał zastosowanych w murach. Tylko w środkowej części ściany północnej stwierdzono piaskowce, podczas gdy w pozostałych częściach tej ściany są to wapienie (ryc. 11), w ponad 70\% drobnodetrytyczne, w ok. 30\% pelityczne i grubodetrytyczne.

Wymiary kształtek wapiennych zastosowanych w murach morawickiego zamku są bardzo podobne do wymiarów kamieni w murach kościołów romańskich Krakowa (Bromowicz, Magiera, 2015). W obu przypadkach ich średnie wysokości są rzędu $12 \mathrm{~cm}$, a długości nieco powyżej $25 \mathrm{~cm}$. Zróżnicowanie, wyrażone współczynnikami zmienności, jest także podobne.

Powyższa zgodność zdaje się potwierdzać, że mury są romańskie. Interesujące jest podobieństwo wspomnianych wymiarów wobec położenia omawianej budowli w pobliżu wychodni górnojurajskich wapieni Jury Krakowsko-Częstochowskiej. Jest ona zapewne pierwszą kamienną budowlą wzniesioną w okolicy. 


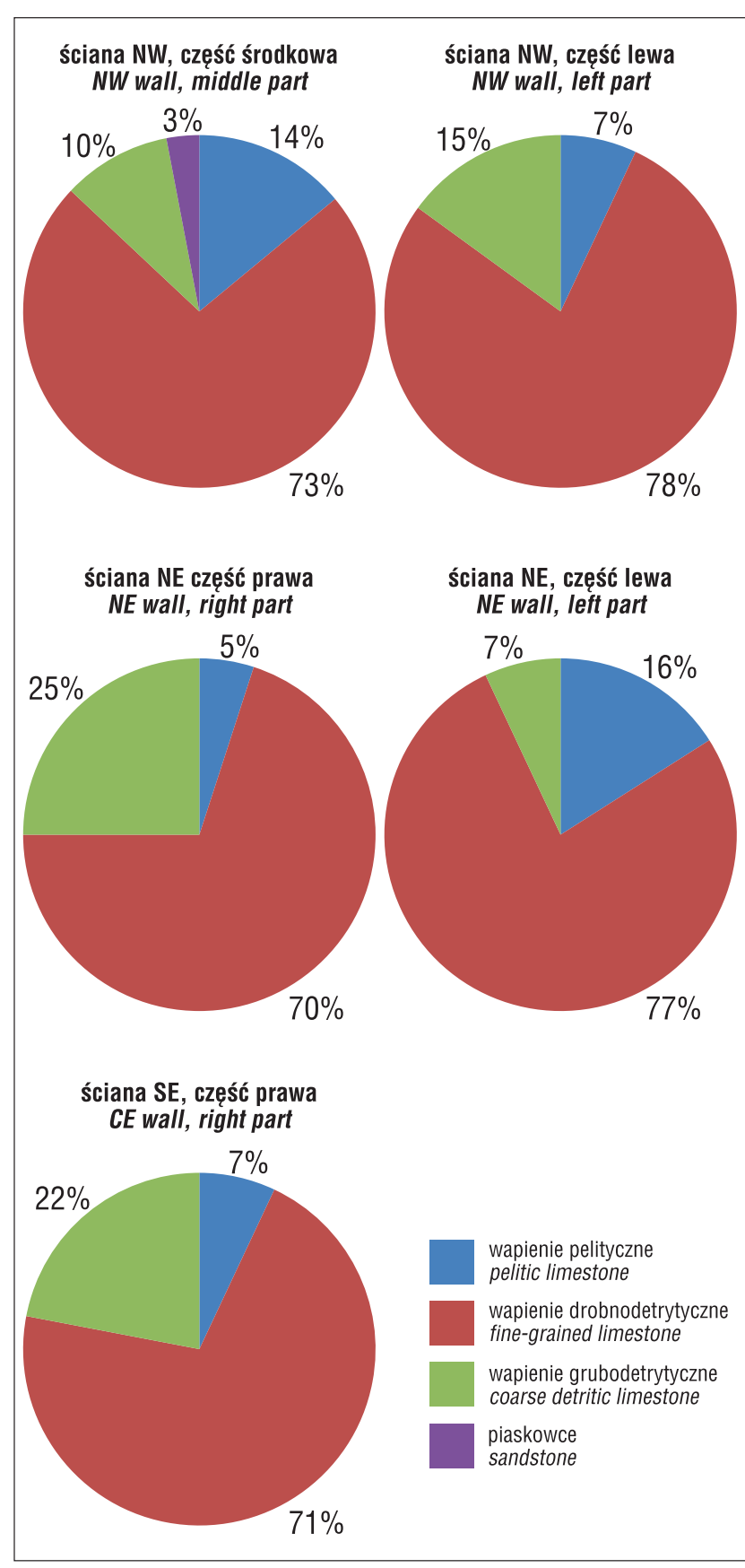

Ryc. 11. Morawica. Odmiany kamieni użytych w zewnętrznych romańskich ścianach plebanii

Fig. 11. Morawica. Rock types applied in external parts of the Romanesque walls of the clergy house

Zastosowanie miejscowego materiału wymagającego zorganizowania wydobycia zwykle skutkowało jego pozyskiwaniem w większych bryłach. Przykładem mogą być budowle podobnie położone, w pobliżu wychodni odpowiednich skał jako materiału budowlanego, jak np. kościół w Wysocicach czy też pobliski klasztor w Tyńcu z wapiennymi bloczkami użytymi w fundamentach, gdzie wymiary tych bloczków są dwukrotnie większe (Bromowicz, Magiera, 2015, 2019). Może być to dowodem na sprowadzenie materiału z kamieniołomów krakowskich, w których surowiec zapewne obrabiano na miejscu. W szczególnie ważnych budowlach krakowskich starano się stosować jak najmniejsze bryły wapienne bez często pojawiających się w tego rodzaju skałach krzemieni. W wapieniach murów kościoła w Wysocicach krzemienie są częste, a nie spotkano ich w budowli morawickiej.

\section{UWAGI KOŃCOWE}

Przeprowadzone obserwacje potwierdzają, że ówcześni budowniczy umieli dobrze zastosować odpowiednie skały w architekturze. Wykorzystywali materiał miejscowy, możliwy do uzyskania w odległościach nie większych niż kilkanaście kilometrów.

W trakcie wznoszenia budowli morawickiej zapewne posłużono się wapieniami wydobywanymi i obrabianymi w istniejących już wtedy krakowskich kamieniołomach. W kościołach położnych na południe od Krakowa zastosowano piaskowce istebniańskie, w formie ciosów o-jak się wydaje - optymalnych dla wydobycia i transportu wymiarach rzędu 20-40 cm. Tylko dla szczególnych zastosowań w prestiżowych budowlach, jak np. Wieża Srebrnych Dzwonów w wawelskiej katedrze, stosowano większe ciosy. Dostrzec można skłonność, znaną już z innych świątyń, do zastosowania specjalnie dobranego materiału w szczególnie ważnych miejscach. W ścianie wewnętrznej, ołtarzowej prezbiterium dziekanowickiego kościoła zastosowano wyselekcjonowane ciosy o wyrównanej wysokości.

Zaznaczają się różnice w umiejętnościach wykonawców budowli. W Dziekanowicach zastosowano ozdobne wsporniki pod stopy sklepienia, zaś pozostały po romańskim kościele w Czchowie fryz, nazwany pseudokymationowym, jest prymitywny. Podobnie wypada porównanie wspomnianych z Czchowa rzeźb, dosyć prymitywnie wykonanego gryfa i postać lwa naturalnej wielkości.

Autorzy bardzo dziękują Recenzentom za cenne i konstruktywne uwagi.

\section{LITERATURA}

BICZ-SUKNAROWSKA M. 2019 - Morawica - romańska siedziba możnowładców małopolskich. Prądnik. Pr. Muz. Szafera, 29: 149-160. BROMOWICZ J., MAGIERA J. 2015 - Kamienie wczesnośredniowiecznych budowli Krakowa ich pochodzenie na tle geologii miasta. Wyd. AGH, Kraków.

BROMOWICZ J., MAGIERA J. 2019 - Skały w architekturze podkrakowskich kościołów romańskich. Prz. Geol., 67 (9): 728-735.

CHRZANOWSKI T. KORNECKI M. 1982 - Sztuka Ziemi Krakowskiej. Wyd. Literackie, Kraków.

DUTKIEWICZ J.E. 1964 - Malowidła romańskie w kościele w Dziekanowicach. Folia Hist. Artium, 1: 55-94.

JODŁOWSKI A. 1977 - Kościół romański w Dziekanowicach, woj. Krakowskie, w świetle badań archeologicznych lat 1974-1975. Acta Archaeolog. Carpat., 17: 231-242.

KURTYKA J. 1995-1996 - Sieciech. Polski Słownik Biograficzny, 36: 495-509.

KWAŚNIK M. 2010 - Morawica? Bogactwo wieków? Dzieje kościoła i parafii. Wyd. Wacław Ziębliński-APW.

ŚWIECHOWSKI Z. 2000 - Architektura romańska w Polsce. Wyd. DiG, Warszawa.

ZOLL-ADAMIKOWA H. 1959 - Grupa kopców w Koźmicach Wielkich pow. Kraków. Acta Archaeolog. Carpat., 1: 121-122.

Praca wpłynęła do redakcji 9.12.2020 r.

Akceptowano do druku 11.01.2021 r. 